\title{
SARS-CoV-2 RT-PCR Pozitif Sağlık Çalışanlarında Serokonversiyon Durumunun Boylamsal İzlenmesi
}

\author{
Longitudinal Monitoring of Seroconversion Status in \\ SARS-CoV-2 RT-PCR Positive Healthcare Workers
}

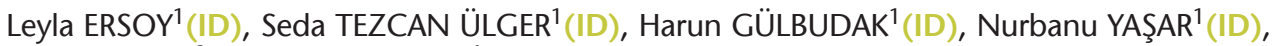 \\ Gülçin YAPICl' ${ }^{2}(I D)$, Gönül ASLAN ${ }^{1}$ (ID) \\ ${ }^{1}$ Mersin Üniversitesi Tıp Fakültesi, Tıbbi Mikrobiyoloji Anabilim Dalı, Mersin. \\ ${ }^{1}$ Mersin University Faculty of Medicine, Department of Medical Microbiology, Mersin, Turkey. \\ 2 Mersin Üniversitesi Tıp Fakültesi, Halk Sağlığı Anabilim Dalı, Mersin. \\ ${ }^{2}$ Mersin University Faculty of Medicine, Department of Public Health, Mersin, Turkey.
}

Makale Atıfı: Ersoy L, Tezcan Ülger S, Gülbudak H, Yaşar N, Yapıcı G, Aslan G. SARS-CoV-2 RT-PCR pozitif sağlık çalışanlarında serokonversiyon durumunun boylamsal izlenmesi. Mikrobiyol Bul 2022;56(1):114-123.

\section{ÖZ}

Şiddetli akut solunum sendromu koronavirüs 2 (SARS-CoV-2)'nin neden olduğu Koronavirüs enfeksiyon hastalığı-2019 (COVID-19) etkisi hala devam etmektedir. COVID-19 hastalığını geçiren bireylerde oluşan immün yanıtın ne kadar süre etkili olduğu ve koruyuculuğu tam olarak anlaşılmamıştır. Bu çalışmada, Mersin Üniversitesi Hastanesinde SARS-CoV-2 gerçek zamanlı revers transkriptaz polimeraz zincir reaksiyonu (rRT-PCR) testi pozitif bulunan sağlık çalışanlarında anti-SARS-CoV-2 serokonversiyon durumlarııı boylamsal olarak değerlendirilmesi amaçlanmıştır. Çalışmaya, 19 Nisan-27 Kasım 2020 tarihleri arasında SARS-CoV-2 rRT-PCR testi pozitif olan, 68 sağlık çalışanı dahil edilmiştir. Sağlık çalışanlarından polimeraz zincir reaksiyonu (PCR) pozitifliğini takip eden 1, 3 ve 5. aylarda SARS-CoV-2 antikor testi için kan örnekleri toplanmıştır. Sağlık çalışanları klinik bulgularına göre semptomatik, asemptomatik ve reenfekte olarak sınıflandııılmış ve rRT-PCR döngü eşik değerleri "Cycle threshold; (Ct)" kaydedilmiştir. Antikor takibi için Elecsys Anti-SARS-CoV-2 (Roche Diagnostics, Almanya) kiti kullanılmışır. Çalışmaya dahil edilen 68 sağlık çalışanının $46^{\prime}$ sı semptomatik, $15^{\prime} \mathrm{i}$ asemptomatik ve yedisi reenfeksiyon geçiren hasta olarak sınıflandırımıştır. Sağlık çalışanlarının 27 (\%39.7)'si erkek, 41 (\%60.3)'i kadın olup yaş ortalaması 36.4 \pm 9.04 'tür. Çalışmadaki 68 sağlık çalışanının 45 (\%66.2)'inde serokonversiyon tespit edilmiş ve yalnız bir kişide beşinci ay sonunda sero-negatifleşme görülmüştür. Semptomatik sağlık çalışanlarının \%78.3 $(n=36 / 46)$ 'ünde serokonversiyon saptanırken asemptomatik olanların \%26.7 $(n=4 / 15)^{\prime}$ 'sinde serokonversiyon görülmüştür. Çalışmada reenfeksiyon gelişen yedi sağlık çalışanının primer enfeksiyon sonrası yalnız birinde serokonversiyon tespit edilmiştir. Reenfeksiyon sonrasında ise beşinde serokonversiyon görülürken ikisinde antikor yanıtı saptanmamışıı. rRT-PCR Ct değeri sonuçlarına baktığımızda; Ct değeri medyanı serokonversiyon tespit edilen sağlık çalışanlarında 23.26 [18.45-27.30], serokonversiyon gelişmeyenlere göre 36.20 [33.09-37.56] istatistiksel olarak daha düşük bulunmuştur $(p<0.001)$. Reenfeksiyon geçirenlerde ise primer enfeksiyon döneminde tespit edilen ortalama Ct değeri (31.77 \pm 6.62$)$ reenfeksiyon sırasında tespit edilen Ct değerinden (22.44 \pm 5.54$)$ istatistiksel olarak daha yüksek bulunmuştur $(p=0.008)$. 
Sağlık çalışanlarında en sık kaydedilen semptomlar; miyalji (\%57.3), halsizlik (\%51.5), baş ağrısı (\%51.5) ve bunları takip eden boğaz ağrısı (\%36.7), ateş (\%33.8), öksürük (\%27.9), diyare (\%23.5) ve dispne (\%16.2) şeklindedir. Ayrıca, serokonversiyon pozitif sağlık çalışanlarındaki ateş (\%52) ve halsizlik (\%80.6) serokonversiyon oluşmayanlara göre istatistiksel olarak anlamlı oranda yüksek bulunmuştur (sırasıyla $p=$ 0.028; $p=0.005$ ). Sonuç olarak, enfeksiyonu semptomatik geçiren sağlık çalışanlarında asemptomatik olanlardan daha yüksek oranda antikor yanıtı saptanmışırı. Primer enfeksiyonu asemptomatik geçiren ve antikor yanıtı oluşmayan hastaların reenfeksiyona daha duyarlı olduğu görülmüştür. Ayrıca semptomatik enfeksiyonlarda viral yük arttıkça (Ct değeri azaldıkça) immün yanıt olasılığının da arttığı ortaya konmuştur. Bu bulgular sağlık personelindeki kısa süreli serokonversiyon durumu ile ilgili önemli bilgiler sağlamasına rağmen; serokonversiyonun uzun süreli etkinliğini değerlendirmek ve SARS-CoV-2 aşı uygulamaları sonrası gelişen immün yanıtın etkinliğini daha iyi anlayabilmek için daha uzun süreli ve daha geniş ölçekli çalışmalara gereksinim vardır.

Anahtar kelimeler: SARS-CoV-2; COVID-19; sağlık çalışanları; antikor; serokonversiyon.

\section{ABSTRACT}

The impact of the coronavirus disease 2019 (COVID-19) pandemic caused by severe acute respiratory syndrome 2 (SARS-CoV-2) still continues. The duration of the immune response in individuals recovering from COVID-19 and its protection against future SARS-CoV-2 infection are not fully understood. This study aimed to longitudinally evaluate anti-SARS-CoV-2 seroconversion status in healthcare workers with positive SARS-CoV-2 Real-time reverse transcription polymerase chain reaction (rRT-PCR), test in Mersin University Hospital. A total of 68 healthcare workers with positive SARS-CoV-2 rRT-PCR test between 19 April and 27 November 2020 were included in the study. Blood samples were collected from healthcare workers for SARS-CoV-2 antibody testing in the $1^{\text {st }}, 3^{\text {rd }}$ and $5^{\text {th }}$ months following PCR positivity. Healthcare workers were classified as symptomatic, asymptomatic and reinfected according to their clinical findings, and rRT-PCR cycle thresholds (Ct) were recorded. Elecsys Anti-SARS-CoV-2 (Roche Diagnostics, Germany) kit was used for antibody testing. Of the 68 healthcare workers; 46 were classified as symptomatic, 15 as asymptomatic, and seven as reinfected. Twenty-seven (39.7\%) of the healthcare workers were male and $41(60.3 \%)$ were female, and the mean age was $36.4 \pm 9.04$. Seroconversion was detected in $45(66.2 \%)$ of 68 healthcare workers in the study, and only one person had sero-negative result at the end of the 5 th month. While seroconversion was detected in $78.3 \%(n=36 / 46)$ of symptomatic healthcare workers, it was observed in $26.7 \%(n=4 / 15)$ of the asymptomatic healthcare workers. Seroconversion was detected in only one of the seven reinfected healthcare workers after primary infection. After reinfection, seroconversion was observed in five of seven reinfected healthcare workers. Antibody response was not detected in two of them after both infections. According to the rRT-PCR Ct values; the median of Ct value was found significantly lower in healthcare workers with seroconversion (23.26, IQR=18.45-27.30), than the ones without seroconversion (36.20, IQR= 33.09-37.56) ( $p<0.001)$. In those who had reinfection, the mean $\mathrm{Ct}$ value $(31.77 \pm 6.62)$ detected during the primary infection period was statistically higher than the $\mathrm{Ct}$ value $(22.44 \pm 5.54)$ detected during reinfection $(\mathrm{p}=0.008)$. The most frequently recorded symptoms in healthcare workers were myalgia $(57.3 \%)$, fatigue $(51.5 \%)$, headache $(51.5 \%)$ followed by sore throat (36.7\%), fever (33.8\%), cough (27.9\%), diarrhea (23.5\%) and dyspnea (16.2\%). In addition, fever (52\%) and fatigue (80.6\%) were found to be significantly higher in seroconversion-positive healthcare workers than in those without seroconversion $(p=0.028 ; p=0.005$, respectively). As a result, a higher rate of antibody response was detected in healthcare workers who had symptomatic infection than those who were asymptomatic. It has been observed that patients with asymptomatic primary infection and without antibody response were more susceptible to reinfection. In addition, it was observed that the probability of immune response increased when the viral load increased (Ct value decreased) in symptomatic infections. Although these findings provide important information about the short-term seroconversion status of healthcare personnel; longer-term and larger-scale studies are needed to evaluate the long-term effectiveness of seroconversion and to better understand the effectiveness of the immune response developed after SARS-CoV-2 vaccine administrations.

Keywords: SARS-CoV-2; COVID-19; healthcare workers; antibody; seroconversion. 


\section{Gíriş}

Aralık 2019'da Çin Hubei Eyaleti Wuhan şehrinde ortaya çıkan ve "Coronavirus Disease 2019 (COVID-19)" hastalığına neden olan "Severe Acute Respiratory Syndrome Coronavirus-2 (SARS-CoV-2)" kısa sürede dünyaya yayılarak 11 Mart 2020'de pandemi seviyesine ulaşmış ve aynı tarihte ülkemizden de ilk olgu bildirilmiştir ${ }^{1,2}$.

COVID-19 tanısında kullanılan standart yöntem gerçek zamanlı revers transkriptaz polimeraz zincir reaksiyonu (rRT-PCR)'dur. COVID-19 ile uyumlu ve rRT-PCR testi negatif saptanan kişilerde, antikor testleri destekleyici tanı testi olarak kullanılabilir ${ }^{3}$. Ancak, SARS-CoV-2 ile enfekte olan her olguda antikor yanıtı gelişip gelişmediği, enfeksiyonun şiddeti ile antikor yanıtı ilişkisi ve antikor yanıtının ne kadar süre devam ettiği bilinmemektedir $^{1}$. Virüs bulaşmasından günler/haftalar sonra üretilen antikor yanıtının gücü; yaş, beslenme, hastalığın şiddeti, bağışıklık sistemini baskılayan enfeksiyonlar ve viral yük gibi çeşitli faktörlere bağlıdır ${ }^{4}$. Şiddetli Orta Doğu solunum sendromu (MERS) olgularında, enfeksiyondan 18 ay sonra antikor tespit edildiği ve antikor yanıtının hastalık şiddeti ile pozitif korelasyon gösterdiği bildirilmiştir ${ }^{5}$. COVID-19 hastalarının çoğunda enfeksiyonu takip eden 10-21. günlerde antikor yanıtı oluşmaktadır. Ancak asemptomatik olgularda antikor yanıtının daha düşük olduğu ya da hiç oluşmadığı bildirilmiştir ${ }^{6,7}$.

Ülke nüfuslarının yaklaşık \%2-3'ünün sağlık çalışanlarından oluştuğu ve bunların \%1435'inin COVID-19 ile enfekte olduğu bildirilmiştir ${ }^{8}$. Ayrıca COVID-19'un sağlık çalışanlarında 12 kat daha fazla görüldüğü raporlanmıştır ${ }^{9}$. Ülkemizde ise 140000 'in üzerinde sağlık çalışanının enfekte olduğu ve 391 sağlık çalışanının hayatını kaybettiği bildirilmiştir $^{10}$. COVID-19 pandemisinde en önemli risk grubu olan sağlık çalışanlarının korunması ve sağlık hizmetlerinin aksamadan yürütülmesi pandeminin öncelikli konulardan birisi olmuştur $^{11}$. COVID-19 hastalığını geçiren bireylerde oluşan immün yanıtın ne kadar süre etkili olduğu ve gelecekteki SARS-CoV-2 enfeksiyonuna karşı koruyuculuğu tam olarak bilinmemektedir.

Bu çalışmada, Mersin Ünivesitesi Hastanesinde SARS-CoV-2 rRT-PCR testi pozitif bulunan sağlık çalışanlarında anti-SARS-CoV-2 serokonversiyon durumlarının boylamsal olarak değerlendirilmesi amaçlanmıştır.

\section{GEREÇ ve YÖNTEM}

Bu çalışma Mersin Üniversitesi Klinik Araştırmalar Etik Kurulu onayı ile gerçekleştirildi (Karar No: 2020/718 ve Tarih: 28/10/2020) ve çalışma için T.C. Sağlık Bakanlığı Sağlık Hizmetleri Genel Müdürlüğü Bilimsel Çalışma Platformundan izin alındı (Tarih: 10.09.2020 ve Karar No: 2020-09-09T15_00_15).

\section{Örneklerin Toplanması}

Çalışmaya, 19 Nisan - 27 Kasım 2020 tarihleri arasında Mersin Üniversitesi Hastanesinde görev yapan, SARS-CoV-2 rRT-PCR testi pozitif bulunan 68 sağlık çalışanı dahil edildi. PCR testi, Bio-speedy kiti (Bioeksen, Türkiye) ile yapıldı. Çalışmada, sağlık çalışanların- 
da oluşan anti-SARS-CoV-2 antikor yanıtı ve serokonversiyon durumu beş aylık süreçte araştırıldı. Kan örnekleri alınmadan önce sağlık çalışanlarına çalışma ile ilgili bilgi verildi. İmmünsupresif ilaç kullanan sağlık çalışanları ve COVID-19 aşısı uygulanan kişiler çalışma dışı bırakıldı.

Çalışmada, birinci kan örneği PCR pozitifliğinden sonraki 26-30. günlerde (birinci ay), ikinci kan örneği 85-95. günlerde (üçüncü ay), üçüncü kan örneği 145-155. günlerde (beşinci ay) alındı. Çalışma periyodu sırasında yedi sağlık çalışanında reenfeksiyon saptandı ve reenfeksiyondan bir ay sonra tekrar kan örneği alındı. Kan örnekleri santrifüjlenerek serumları ayrıldı ve çalışma yapılıncaya kadar $-20^{\circ} \mathrm{C}^{\prime}$ de saklandı.

Çalışmadaki sağlık çalışanlarının COVID-19 ile ilgili klinik kayıtları hastane bilgi sisteminden alındı ve hastaların rRT-PCR sonucunda viral yük göstergesi olan döngü eşik değeri "Cycle threshold (Ct)" verileri kaydedildi.

Çalışmada sağlık çalışanları üç grup halinde izlendi. Birinci grup $(n=46)$; hastaneye yatışı olmayan semptomatik seyirli kişilerden; 2. grup ( $n=15)$; asemptomatik kişilerden ve 3. grup $(n=7)$ ise reenfekte olan kişilerden (primer enfeksiyondan sonra SARS-CoV-2 PCR testi negatifleşen ve yaklaşık 4-6 ay sonra PCR testi tekrar pozitif olan sağlık personellerinden) oluştu.

\section{SARS-COV-2 Antikor Testi}

Çalışmada SARS-CoV-2 antikor tespiti için; elektrokemilüminesans immünoassay (ECLIA) prensibi ile çalışan ve virüsün $N$ proteinine karşı oluşan total antikor yanıtını saptayan Elecsys Anti-SARS-CoV-2 (Roche Diagnostics, Almanya) kiti kullanıldı. Testler üretici firmanın talimatları doğrultusunda kit ile uyumlu Cobas e 601 (Roche Diagnostics, Almanya) cihazında çalışıldı. Cut-off indeksi (COI) < 1.0 olan serum örnekleri non-reaktif (SARSCoV-2 antikor yanıtı negatif), COI $\geq 1$ olan serum örnekleri reaktif (SARS-CoV-2 antikor yanıtı pozitif) olarak değerlendirildi.

\section{İstatistiksel Analiz}

Sürekli değişkenlerin normallik kontrolü Shapiro Wilk testi ile değerlendirildi. Normal dağılıma uygunluk gösteren değişkenlerde parametrik, göstermeyenlerde nonparametrik yöntemler kullanıldı. Bağımsız iki grup karşılaştırmasında Student's t test ve Mann-Whitney U testleri uygulandı. Bağımlı iki grup için eşleştirilmiş t testi ve Wilcoxon testi kullanıldı. Bağımlı ikiden fazla grubun karşılaştırmaları ise Friedman testi ile değerlendirildi. Kategorik verilerin analizinde ki-kare ve Fisher's exact testleri uygulandı. İstatistik anlamlılık seviyesi $\mathrm{p}<0.05$ olarak alınmış olup, verilerin analizi SPSS ("Statistical Package for the Social Sciences") 21 programında yapıldı.

\section{BULGULAR}

Çalışmaya dahil edilen 68 sağlık çalışanının yaş ortalaması $36.4 \pm 9.04$ olup \%60.3 $(\mathrm{n}=41)^{\prime}$ ü kadındır (Tablo I). Çalışmada sağlık çalışanı hastaların 45 (\%66.2)'inde sero- 


\begin{tabular}{|c|c|c|c|c|c|}
\hline & $\begin{array}{c}\text { Asemptomatik } \\
n=15(\%)\end{array}$ & $\begin{array}{c}\text { Semptomatik } \\
n=46(\%)\end{array}$ & $\begin{array}{c}\text { Reenfekte } \\
n=7(\%)\end{array}$ & $\begin{array}{c}\text { Toplam } \\
n=68(\%)\end{array}$ & $\mathbf{p}$ \\
\hline \multicolumn{6}{|l|}{ Cinsiyet } \\
\hline Kadın & $8(19.5)$ & $28(68.3)$ & $5(12.2)$ & $41(60.3)$ & $0.714^{a}$ \\
\hline Erkek & $7(25.9)$ & $18(66.7)$ & $2(7.4)$ & $27(39.7)$ & \\
\hline \multicolumn{6}{|l|}{ Komorbiditeler } \\
\hline Var & $1(11.1)$ & $7(77.8)$ & $1(11.1)$ & $9(13.2)$ & $0.695^{\mathrm{a}}$ \\
\hline Yok & $14(23.7)$ & $39(66.1)$ & $6(10.2)$ & $59(86.8)$ & \\
\hline \multicolumn{6}{|l|}{ Çalıştığı birim } \\
\hline COVID-19 servis & $5(38.4)$ & $6(46.2)$ & $2(15.4)$ & $13(19.1)$ & $0.268^{a}$ \\
\hline Diğer servisler & $8(19.0)$ & $29(69.0)$ & $5(12.0)$ & $42(61.8)$ & \\
\hline İdari ve teknik birimler & $2(15.4)$ & $11(84.6)$ & $0(0.0)$ & $13(19.1)$ & \\
\hline Yaş (Ort. $\pm S D$ ) & $39.87 \pm 8.07$ & $36.98 \pm 8.55$ & $30.71 \pm 9.69$ & $36.4 \pm 9.04$ & $0.103^{b}$ \\
\hline
\end{tabular}

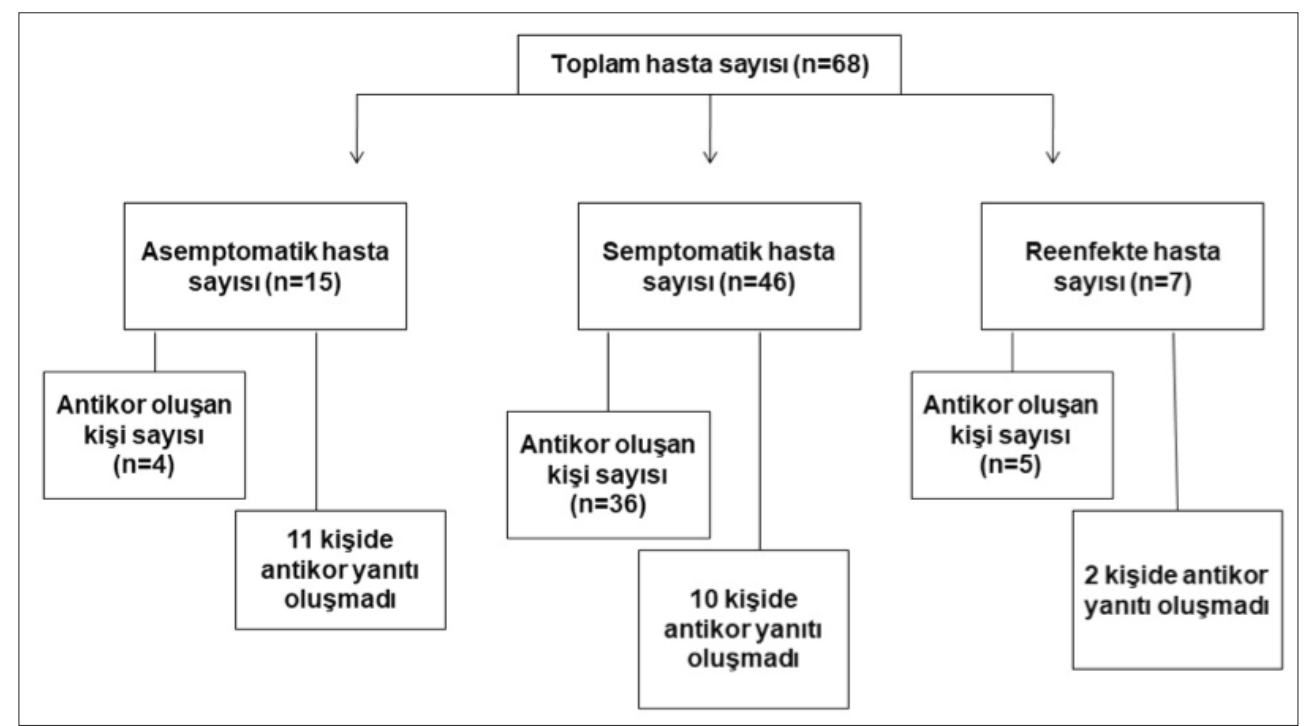

Şekil 1. Sağlık personeli hastaların serokonversiyon durumu özeti.

konversiyon tespit edilirken 23 (\%33.8)'ünde serokonversiyon gözlenmemiştir (Şekil 1). Antikor yanıtı saptanan sağlık çalışanlarının birinde beşinci ay sonunda seronegatifleşme görülmüştür.

rRT-PCR Ct sonuçları değerlendirildiğinde; Ct değeri medyanı serokonversiyon tespit edilen sağlık çalışanlarında 23.26 [18.45-27.30], serokonversiyon gelişmeyenlere göre 
36.20 [33.09-37.56] anlamlı olarak daha düşük bulunmuştur $(\mathrm{p}<0.001)$ (Tablo II). Ct değeri medyanı, semptomatik hastalık gelişen sağlık çalışanlarında da 25.11 [20.44-28.81] asemptomatik olanlardan 35.38 [20.05-38.0] daha düşük saptanmıştır $(p=0.041)$.

Semptomatik sağlık çalışanlarında en sık kaydedilen bulgular; miyalji (\%57.3), halsizlik (\%51.5), baş ağrısı (\%51.5) ve bunları takip eden boğaz ağrısı (\%36.7), ateş (\%33.8), öksürük (\%27.9), diyare (\%23.5) ve dispne (\%16.2) şeklindedir. Semptomatik grupta, serokonversiyon pozitif sağlık çalışanlarındaki ateş (\%52) ve halsizlik (\%80.6) serokonversiyon oluşmayanlara göre anlamlı oranda yüksek bulunmuştur (sırasıyla $p=0.028 ; p=$ 0.005).

Semptomatik sağlık çalışanlarının \%78.3 (n= 36/46)'ünde PCR pozitifliğini takip eden 1,3 ve 5 . aylarda alınan serum örneklerinde serokonversiyon saptanırken \%21.7 ( $n=$ 10/46)'sinde antikor yanıtı tespit edilmemiştir. Asemptomatik sağlık çalışanlarının \%73.3 ( $n=11 / 15)^{\prime}$ ünde antikor yanıtı saptanmamış; \%26.7 $(n=4 / 15)^{\prime}$ sinde ise beş ay boyunca antikor pozitifliğinin devam ettiği görülmüştür (Şekil 1).

Semptomatik grupta yer alan ve serokonversiyon gelişen 36 sağlık çalışanının beş aylık serokonversiyon takibi sonucunda birinci ay cut off indeksinin (COI) üçüncü ayda arttığı ancak beşinci ayda azalmaya başladığı tespit edilmiştir (Tablo III). Antikor yanıtı oluşan 36 sağlık çalışanının antikor COI medyanları incelendiğinde 19'unda birinci ayda elde edilen antikor yanıtının (26.99 [1.58-69.48]) üçüncü ayda arttığı (68.17 [7.82-138.2]) ve beşinci ayda azaldığı (57 [5.81-98.5]); 11'inde antikor yanıtının birinci aydan beşinci

\begin{tabular}{|c|c|c|c|}
\hline \multirow[t]{2}{*}{ Hastalar } & \multicolumn{2}{|c|}{ qRT-PCR Ct değeri } & \multirow[b]{2}{*}{$p$} \\
\hline & $\begin{array}{l}\text { Serokonversiyon oluşan } \\
\qquad(n=45)\end{array}$ & $\begin{array}{l}\text { Serokonversiyon oluşmayan } \\
\qquad(n=23)\end{array}$ & \\
\hline & n (Medyan[IQR]) & n (Medyan[IQR]) & \\
\hline Semptomatik & $36(22.02[18.98-25.11])$ & $10(36.02[29.75-37.21])$ & $<0.001$ \\
\hline Asemptomatik & $4(17.20$ [14.58-19.49]) & $11(36.64[35.34-38.60])$ & 0.001 \\
\hline Reenfekte & 5 (28.71 [24.16-30.92]) & 2 (25.46 [19.37-*]) & 0.857 \\
\hline Toplam & $45(23.26[18.45-27.30])$ & $23(36.20[33.09-37.56])$ & $<0.001$ \\
\hline
\end{tabular}

\begin{tabular}{lcccc}
\multicolumn{5}{l}{ Tablo III. Semptomatik Sağlık Çalışanlarının Serokonversiyon Cut-off indeksleri } \\
\hline Ort \pm SS & Medyan [IQR] & Min-Maks & p \\
\hline COI/1. ay & $36.18 \pm 43.06$ & $17.08[1.83-61.64]$ & $0.99-160.3$ & \\
COI/3. ay & $59.63 \pm 62.44$ & $27.36[7.24-121.18]$ & $1.39-180$ & 0.001 \\
COI/5. ay & $44.97 \pm 50.65$ & $14.26[4.87-97.9]$ & $0.99-180$ & \\
\hline
\end{tabular}

p: Friedman testi.

Ort: Ortalama, SS: Standart sapma, COI: Cut-off indeksi. 
aya doğru düşüş eğilimi gösterdiği (16.92 [8.61-32.12] > 13 [4.77-23.95] > 9.1 [2.3417.52]); diğer altısında ise birinci aydan beşinci aya doğru artış eğilimi olduğu (18.29 [0.99-116.2] < 86.58 [1.77-129.28] < 100.85 [6.39-147]) saptanmıştır.

Çalışmaya dahil edilen sağlık çalışanlarının 7 (\%10.3)'sinde reenfeksiyon tespit edilmiştir ve bu kişilerin ikisinde primer enfeksiyon ve reenfeksiyon sırasında semptomik bulgular görülürken beşinde sadece reenfeksiyon sırasında semptom gelişmiştir. Bu gruptaki yedi sağlık çalışanının primer enfeksiyon sonrası yalnız birinde serokonversiyon tespit edilmiştir. Reenfeksiyon sonrasında ise beşinde serokonversiyon görülürken; ikisinde antikor yanıtı saptanmamıştır (Şekil 1). Bu grubun primer enfeksiyon döneminde tespit edilen ortalama Ct değeri (31.77 \pm 6.62$)$ reenfeksiyon sırasındakinden (22.44 \pm 5.54$)$ anlamlı olarak daha yüksek bulunmuştur $(p=0.008)$.

\section{TARTIŞMA}

Antikor yanıtı koruyucu bağışıkığın bir göstergesidir. Ancak COVID-19 geçiren hastalarda SARS-CoV-2 antikor seviyesinin değişken olduğu bildirilmiştir ${ }^{12}$. Ayrıca, enfeksiyon sonrası oluşan bağışıklığın kişiyi yeni bir enfeksiyondan ne kadar süre koruduğu hala kesin olarak bilinmemektedir ${ }^{13}$. Yapılan çalışmalarda, enfeksiyondan birkaç hafta sonra, SARS-CoV-2 N proteinine, S glikoproteinine ve reseptör bağlanma (RBD) bölgelerine karşı antikor yanıtı oluştuğu ve oluşan antikorların en az altı ay boyunca serumda saptanabildiği gösterilmiştir ${ }^{14}$. Çalışmamızda beş aylık sürede $N$ proteinine karşı total antikor yanıtı takip edilmiştir. Altmış sekiz sağlık çalışanın, \%66.2 ( $n=45)^{\prime}$ sinde serokonversiyon görülmüş ve yalnız birinde beşinci ayda sero-negatifleşme tespit edilmiştir. Wajnberg ve arkadaşları $^{15}$, SARS-CoV-2 S proteinine karşı oluşan nötralizan antikorların, primer enfeksiyondan sonra en az beş ay boyunca tespit edildiğini bildirmiştir. Sağlık çalışanları ile yapılan bir çalışmada ${ }^{12}$, SARS-CoV-2 anti-N IgG antikor yanıtının 85 güne kadar, anti-S IgG yanıtının ise 180 güne kadar uzayabildiği bildirilmiştir.

Çalışmada elde ettiğimiz bulgular, semptomatik ve asemptomatik sağlık çalışanlarında farklı serokonversiyon dinamikleri olduğunu göstermiştir. Semptomatik sağlık çalışanlarının \%78.3 ( $n=36 / 46)^{\prime}$ ünde, asemptomatik olanların ise \%26.7 ( $\left.n=4 / 15\right)^{\prime}$ sinde serokonversiyon tespit edilmiştir. Ayrıca semptomatik grupta antikor yanıtı oluşan 36 sağlık çalışanının beş aylık serokonversiyon takibi sonucunda antikor COI medyanları incelendiğinde; birinci ayda elde edilen antikor yanıtının üçüncü ayda artma ve beşinci ayda azalma eğiliminde olduğu saptanmıştır. Çin'de yapılan bir çalışmada ${ }^{16}, 11^{\prime}$ 'i ağır semptomatik, beşi semptomatik ve beşi asemptomatik olan toplam 21 hastanın serokonversiyon oranları sırasıyla \%100 ( $\mathrm{n}=11 / 11), \% 100(n=5 / 5), \% 20(n=1 / 5)$ olarak saptandığı, toplamda \%80.95 ( $n=17 / 21)^{\prime}$ inde serokonversiyon gözlendiği ve antikor yanıtının iki ay boyunca korunduğu bildirilmiştir. Long ve arkadaşlarının COVID-19 immünolojisini değerlendirdikleri çalışmada ${ }^{6}$, IgG antikor seviyesi asemptomatik bireylerde, semptomatik hastalardan daha düşük bulunmuştur. Ayrıca, iyileşme döneminde asemptomatik bireylerin \%40'ının, semptomatik hasta grubunun ise \%12.9'unun sero-negatif hale geldiği bildirilmiştir. Çalışmamızdan elde ettiğimiz sonuçlar ve diğer çalışmalar, asemptomatik hastaların daha düşük serokonversiyon oranına sahip olduğunu göstermektedir. 
SARS-CoV-2 ile enfekte hastalar, hafif enfeksiyondan yoğun bakım tedavisi gerektiren şiddetli enfeksiyona kadar değişen geniş spektrumlu bir klinik seyir göstermekte ve asemptomatik hastalar COVID-19'un yayılmasında önemli rol oynamaktadır ${ }^{17}$. Çalışmamızda, sağlık çalışanlarının \%22'sinde enfeksiyonun asemptomatik seyrettiği, semptomatik hastalarda miyalji (\%57.3), halsizlik (\%51.5) ve baş ağrısının (\%51.5) en sık görülen semptomlar olduğu tespit edilmiştir. Bir çalışmada ${ }^{18}$ semptomatik 172 COVID-19 hastasında en sık görülen semptomların öksürük (\%40.1), hipozmi (\%39.5) ve balgam çıkarma (\%39.5) olduğu; ateşin ise \%11.6 oranında tespit edildiği bildirilmiştir. Çalışmamızda, serokonversiyon gelişen semptomatik hastaların $\% 52.7$ 'sinde ateş $(p=0.028)$ ve $\% 80.6$ 'sında halsizlik $(\mathrm{p}=0.005)$ bulgularının, serokonversiyon gelişmeyenlerden daha yüksek olduğu saptanmıştır.

SARS-CoV-2'ye karşı antikor yanıtı gelişen bireylerin, antikor negatif bireylere göre reenfeksiyon riskinin daha düşük olduğu gösterilmiştir ${ }^{19,20}$. Bu çalışmada sağlık çalışanlarının 7 (\%10.3)'sinde reenfeksiyon tespit edilmiştir. Bu yedi hastanın primer enfeksiyonu sonrasında yalnız birinde serokonversiyon saptanırken, reenfeksiyon sonrasında ise yedi hastanın beşinde serokonversiyon tespit edilmiştir. Ingiltere'de yapılan geniş ölçekli bir çalışmada ${ }^{21}$, geçirilen SARS-CoV-2 enfeksiyonunun reenfeksiyon riskini \%84 oranında azalttığı ve primer enfeksiyonda gelişen bağışıklığın koruyucu etkisinin yedi ay kadar sürdüğü bildirilmiştir. Ancak reenfeksiyon süresinin 1-2 ay gibi çok daha kısa sürede olabileceğini de gösteren olgular bildirilmiştir ${ }^{22,23}$.

SARS-CoV-2 enfeksiyonu geçiren kişilerde oluşan anitikor yanıtının hastalığın şiddeti ve viral yük ile ilişkili olabileceği bildirilmiştir ${ }^{7,24}$. 222 hastanın antikor yanıtının değerlendirildiği bir çalışmada ${ }^{24} \mathrm{lgG}$ antikor yanıtının artışı COVID-19 hastalığının şiddeti ile ilişkili bulunmuştur. Ct değeri ile IgG antikor yanıtının negatif korelasyon gösterdiği bildirilen bir çalışmada 7,137 ( $n=111$ semptomatik; $n=26$ asemptomatik) hastanın IgG antikor yanıtının, asemptomatik hastalarda (\%15.4) semptomatik hastalardan (\%85.1) daha düşük olduğu tespit edilmiş ve asemptomatik hastaların Ct değerinin semptomatik olanlardan 5-7 birim daha yüksek olduğu belirtilmiştir. Çalışmamızda Ct değeri medyanı serokonversiyon tespit edilen sağlık çalışanlarında 23.26 [18.45-27.30], serokonversiyon gelişmeyenlere göre 36.20 [33.09-37.56] istatistiksel olarak daha düşük bulunmuştur $(p<0.001)$. Ct değeri medyanı, semptomatik hastalık gelişen sağlık çalışanlarında da 25.11 [20.44-28.81] asemptomatik olanlardan 35.38 [20.05-38.0] istatistiksel olarak daha düşük saptanmıştır $(p=0.041)$. Bu bulgular viral yük ile semptomatik enfeksiyonun ve immün yanıtın ilişkili olduğunu göstermektedir. Buna göre Ct değeri azaldıkça (viral yük arttıkça) semptomatik enfeksiyon olasılığı ve immün yanıt olasılığı artmaktadır.

Sonuç olarak, çalışmada sağlık çalışanlarındaki serokonversiyon durumu beş ay boyunca takip edilmiş ve 68 sağlık çalışanının \%66.2 ( $n=45)^{\prime}$ 'sinde SARS-CoV-2 antikor yanıtı saptanmıştır. Antikor yanıtı saptanan sağlık çalışanlarından yalnız birinde beşinci ay sonunda sero-negatifleşme görülmüştür. Enfeksiyonu semptomatik geçiren sağlık çalışanlarında asemptomatik olanlardan daha yüksek oranda antikor yanıtı saptanmıştır. Pri- 
mer enfeksiyonu asemptomatik geçiren ve antikor yanıtı oluşmayan hastaların reenfeksiyona daha duyarlı olduğu görülmüştür. Ayrıca semptomatik enfeksiyonlarda viral yük arttıkça (Ct değeri azaldıkça) immün yanıt olasılığının da arttığı ortaya konmuştur. Bu bulgular sağlık personelindeki kısa süreli serokonversiyon durumu ile ilgili önemli bilgiler sağlamasına rağmen serokonversiyonun uzun süreli etkinliğini değerlendirmek ve SARSCoV-2 aşı uygulamaları sonrası gelişen immün yanıtın etkinliğini daha iyi anlayabilmek için daha uzun süreli ve daha geniş ölçekli çalışmalara gereksinim vardır.

\section{ETIK KURUL ONAYI}

Bu çalışma Mersin Üniversitesi Klinik Araştırmalar Etik Kurulu onayı ile gerçekleştirildi (Karar No: 2020/718 ve Tarih: 28/10/2020) ve çalışma için T.C. Sağlık Bakanlığı Sağlık Hizmetleri Genel Müdürlüğü Bilimsel Çalışma Platformundan izin alındı (Tarih: 10.09.2020 ve Karar No: 2020-09-09T15_00_15).

\section{ÇIKAR ÇATIŞMASI}

Yazarlar bu makale ile ilgili herhangi bir çıkar çatışması bildirmemişlerdir.

\section{KAYNAKLAR}

1. Krammer F, Simon V. Serology assays to manage COVID-19. Science 2020; 368(6495): 1060-1.

2. T.C. Sağlık Bakanlığı Halk Sağlığı Genel Müdürlüğü. COVID-19 (SARS-CoV-2 Enfeksiyonu) Genel Bilgiler, Epidemiyoloji ve Tanı. Bilimsel Danışma Kurulu Çalışması. Ankara, 7 Aralık 2020, S:5.

3. Knight D, Irizarry-Alvarado J. SARS-CoV-2 serological testing changes disease management in a PCR-negative patient. BMJ Case Rep 2020; 13(8): e237239.

4. World Health Organization (WHO). Advice on the use of point-of-care immunodiagnostic tests for COVID-19 Scientific brief. Available from: https://apps.who.int/iris/bitstream/handle/10665/331713/ WHO-2019-nCoV-Sci_Brief-POC_immunodiagnostics-2020.1 eng.pdf?sequence $=1$ \&is Allowed=y (Accessed date: 8 April 2020).

5. Alshukairi AN, Khalid I, Ahmed WA, Dada AM, Bayumi DT, Malic LS, et al. Antibody response and disease severity in healthcare worker MERS survivors. Emerg Infect Dis 2016; 22(6): 1113-5.

6. Long QX, Tang XJ, Shi QL, Li Q, Deng HJ, Yuan J, et al. Clinical and immunological assessment of asymptomatic SARS-CoV-2 infections. Nat Med 2020; 26(8): 1200- 04.

7. Wellinghausen N, Plonné D, Voss M, Ivanova R, Frodl R, Deininger S. SARS-CoV-2-lgG response is different in COVID-19 outpatients and asymptomatic contact persons. J Clin Virol 2020; 130: 104542.

8. WHO. Keep health workers safe to keep patients safe. News release Geneva. Available from: https://www. who.int/news/item/17-09-2020-keep-health-workers-safe-to-keep-patients-safe-who (Accessed date: 17 September 2020).

9. Nguyen LH, Drew DA, Joshi AD, Guo CG, Ma W, Mehta RS, et al. Risk of COVID-19 among frontline healthcare workers and the general community: a prospective cohort study. Lancet Public Health 2020; 5(9): e475-83

10. Türk Tabipleri Birliği. COVID-19 Nedeniyle Kaybettiğimiz Sağlık Çalışanları Türkiye'nin Her Yerinde Anıldı. Available from: https://www.ttb.org.tr/kollar/COVID19/haber_goster.php?Guid=97bfa578-92f1-11eb9b30-af7a56403e78 (Accessed date: 1 April 2021).

11. De Carlo A, Lo Caputo S, Paolillo C, Rosa AM, D'Orsi U, De Palma M, et al. SARS-COV-2 serological profile in healthcare professionals of a Southern Italy Hospital. Int J Environ Res Public Health 2020; 17(24): 9324. 
12. Lumley SF, Wei J, O'Donnell D, Stoesser NE, Matthews PC, Howarth A, et al. The duration, dynamics and determinants of acute respiratory syndrome Coronavirus 2 (SARS-CoV-2) antibody responses in individual healthcare workers. Clin Infect Dis 2021; 73(3): e699-e709.

13. Hanrath AT, Payne BAI, Duncan CJA. Prior SARS-CoV-2 infection is associated with protection against symptomatic reinfection. J Infect 2021; 82(4): e29-e30.

14. L'Huillier AG, Meyer B, Andrey DO, Arm-Vernez I, Baggio S, Didierlaurent A, et al. Antibody persistence in the first 6 months following SARS-CoV-2 infection among hospital workers: a prospective longitudinal study. Clin Microbiol Infect 2021; 27(5): e1-e8.

15. Wajnberg A, Amanat F, Firpo A, Altman DR, Bailey MJ, Mansour M, et al. Robust neutralizing antibodies to SARS-CoV-2 infection persist for months. Science 2020; 370(6521): 1227-1230.

16. Yongchen Z, Shen H, Wang X, Shi X, Li Y, Yan J, et al. Different longitudinal patterns of nucleic acid and serology testing results based on disease severity of COVID-19 patients. Emerg Microbes Infect 2020; 9(1) :833-36.

17. Yu P, Zhu J, Zhang Z, Han Y. A familial cluster of infection associated with the 2019 novel coronavirus indicating possible person-to-person transmission during the incubation period. J Infect Dis 2020; 221(11): 1757-61.

18. Kim GU, Kim MJ, Ra SH, Lee J, Bae S, Jung J, et al. Clinical characteristics of asymptomatic and symptomatic patients with mild COVID-19. Clin Microbiol Infect 2020; 26(7): 948.e1-948.e3.

19. Lumley SF, O'Donnell D, Stoesser NE, Matthews PC, Howarth A, Hatch SB, et al. Antibody status and incidence of SARS-CoV-2 infection in health care workers. N Engl J Med 2021; 384(6): 533-40.

20. Addetia A, Crawford KHD, Dingens A, Zhu H, Roychoudhury P, Huang ML, et al. Neutralizing antibodies correlate with protection from SARS-CoV-2 in humans during a fishery vessel outbreak with a high attack rate. J Clin Microbiol 2020; 58(11): e02107-20.

21. Hall VJ, Foulkes S, Charlett A, Atti A, Monk EJM, Simmons R, et al. SARS-CoV-2 infection rates of antibody-positive compared with antibody-negative health-care workers in England: a large, multicentre, prospective cohort study (SIREN). Lancet 2021; 397(10283): 1459-69.

22. Tillett RL, Sevinsky JR, Hartley PD, Kerwin H, Crawford N, Gorzalski A, et al. Genomic evidence for reinfection with SARS-CoV-2: a case study. Lancet Infect Dis 2021; 21(1): 52-8.

23. Prado-Vivar B, Becerra-Wong M, Guadalupe JJ, Márquez S, Gutierrez B, Rojas-Silva P, et al. A case of SARSCoV-2 reinfection in Ecuador. Lancet Infect Dis 2021; 21(6) :e142.

24. Zhang B, Zhou X, Zhu C, Song Y, Feng F, Qiu Y, et al. Immune phenotyping based on the neutrophil-to-lymphocyte ratio and IgG level predicts disease severity and outcome for patients with COVID-19. Front Mol Biosci 2020; 7: 157. 